\title{
Training and exchange of best practices as a tool towards supervisory convergence
}

\author{
Robbert Jaspers ${ }^{1}$
}

Published online: 14 July 2016

(C) ERA 2016

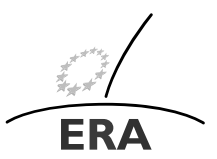

EUROPÄISCHE RECHTSAKADEMIE ACADEMY OF EUROPEAN LAW ACADEMIE DE DROIT EUROPEEN ACCADEMIA DI DIRITTO EUROPEO TRIER - TREVES - TREVIRI

One of the missions of the European Supervisory Authorities established within the framework of the European System of Financial Supervision is fostering supervisory convergence across the EU. In that sense, recital 40 of Regulation 1095/2010 establishing the European Securities Markets Authority (ESMA) ${ }^{1}$ states that ESMA should actively foster supervisory convergence across the Union with the aim of establishing a common supervisory culture. Similar statements can be found in the regulations establishing the European Insurance and Occupational Pensions Authority $(\text { EIOPA })^{2}$ and the European Banking Authority (EBA). ${ }^{3}$

So, what does supervisory convergence mean? The ultimate aim of furthering supervisory convergence is to establish a common supervisory culture. This common supervisory culture is needed as merely focusing on creating a single rulebook is not

\footnotetext{
${ }^{1}$ Regulation (EU) No 1095/2010 of the European Parliament and of the Council of 24 November 2010 establishing a European Supervisory Authority (European Securities and Markets Authority), amending Decision No 716/2009/EC and repealing Commission Decision 2009/77/EC, OJ L 331 of 15 December 2010, pp. 84-119.

${ }^{2}$ Regulation (EU) No 1094/2010 of the European Parliament and of the Council of 24 November 2010 establishing a European Supervisory Authority (European Insurance and Occupational Pensions Authority), amending Decision No 716/2009/EC and repealing Commission Decision 2009/79/EC, OJ L 331 of 15 December 2010, pp. 48-83, at recital 39.

${ }^{3}$ Regulation (EU) No 1093/2010 of the European Parliament and of the Council of 24 November 2010 establishing a European Supervisory Authority (European Banking Authority), amending Decision No 716/2009/EC and repealing Commission Decision 2009/78/EC, OJ L 331 of 15 December 2010, pp. 1247 , at recital 40 .
}

R. Jaspers

rjaspers@era.int

1 Business Law, Metzer Allee 4, 54295 Trier, Germany 
sufficient to create a level-playing field across the banking and financial sector in the EU. What is needed - in addition-is a common approach to how the rules are supervised. As the European System of Financial Supervision relies heavily on the national competent authorities to supervise the financial sector, it is necessary that the various national competent authorities in the 28 Member States have a harmonised approach to supervision, in addition to common rules. Creating a level-playing field of financial supervision is important in order to avoid regulatory arbitrage, or better supervisory arbitrage, within the EU across the different Member States. Supervisory arbitrage should be avoided at all costs to ensure the uniformity of application of rules and fair competition within the EU. Ideally, it should not be possible under the single rulebook for firms to opt for the most convenient supervisor.

Supervisory convergence has become a priority of the European Supervisory Authorities recently. ESMA has recently emphasised the importance of supervisory convergence by issuing its first supervisory convergence work programme in February 2016. ${ }^{4}$ ESMA is planning to shift some of its resources from single rulebook work to working on supervisory convergence. In addition, ESMA has set up a standing committee on supervisory convergence ${ }^{5}$ and the first peer review on the suitability requirements in the context of the Markets in Financial Instruments Directive (MiFID) has been published. EBA and EIOPA also frequently emphasise the importance of supervisory convergence. EBA, for example, issued a report on convergence of supervisory practices in April 2015. ${ }^{6}$ In November 2015, Gabriel Bernardino, the chairman of EIOPA, gave a speech at a conference in Milan entitled "The Journey towards Supervisory Convergence begins" in which he made clear that the European supervisory system will only be as strong as its weakest link, and that working on supervisory convergence will be EIOPA's important task for the next five years.

One of the tools specifically mentioned in the regulations establishing the European Supervisory Authorities is training as a means to improve supervisory convergence. Other tools to achieve supervisory convergence are: the provision of opinions to national competent authorities, exchange of information between competent authorities, the development of uniform supervisory standards, and peer reviews. In addition, Article 29 of Regulation 1095/2010 explicitly refers to training as one of the activities to establish a common supervisory culture. Training can indeed contribute to a common understanding of the rules and create a common approach on how to supervise them. Through gathering representatives from different competent authorities in one seminar, conference or workshop exchanges of best practices can be encouraged, and the first steps towards a common supervisory culture can be made.

\footnotetext{
${ }^{4}$ ESMA Supervisory Convergence Work Programme 2016, ESMA/2016/203, 11 February 2016.

${ }^{5}$ Terms of reference for the Supervisory Convergence Standing Committee, ESMA/2016/229, 27 January 2016.

${ }^{6}$ EBA Report on Convergence of Supervisory Practices, April 2015, available at: https://www.eba.europa. eu/documents/10180/950548/Supervisory+convergence+report.pdf/9f49ddf9-232f-4062-b34eff671d440081.

${ }^{7}$ Keynote speech: EIOPA: The Journey towards Supervisory Convergence Begins, 26 November 2015 held at the Catholic University of Sacred Heart Milan, available at: https://eiopa.europa.eu/Publications/ Speeches\%20and\%20presentations/2015-11-26\%20Conference\%20by\%20Catholic\%20University\% 20of $\% 20$ Sacred $\% 20$ Heart.pdf.
} 
Training is at the core of ERA's mission. It is the mission of ERA to enable individuals and authorities involved in the application and implementation of European law to gain a wider knowledge of European law, and to make possible a mutual and comprehensive exchange of experiences. This mission proves to be compatible with providing training to foster supervisory convergence across the EU. Through conferences that offer the opportunity to exchange experiences in the application of European Union law, ERA can enable supervisors to learn from each other's best practices. Therefore, there seems to be a direct link between ERA's mission and the tasks of the ESAs to contribute to supervisory convergence.

Within the framework of several conferences, ERA has proven to be a place where supervisory best practices can be (and were indeed) exchanged. A good example of this is the annual conference on financial supervision in the EU, for at last year's conference, there was an interesting exchange on the topic of bank resolution, with contributions and insights from different Member States. Another good example of such an exchange was an event on best practices in financial supervision, which focused on supervising within the legal framework on market abuse. Opened by a representative of ESMA, the conference followed the different steps in market abuse investigations as seen through the eyes of representatives from various national competent authorities. Discussions at this conference were lively and lengthy, with participants and speakers from more than ten different national authorities contributing to make a very engaging exchange of experiences. Another fine example of an ERA training format that can play a role in creating a common supervisory culture is ERA's five day summer course on financial supervision and regulation in the EU, which takes place in Trier on a yearly basis at the end of June. This summer course, which is among others targeted at young professionals starting a career at one of the several national competent authorities in the EU, gathered more than 60 participants last year, who received training on different topics relevant to financial supervisors. Whereas this course may not be tailored to provide for an exchange of best practices, nevertheless, through the different presentations and workshops, it does create a common understanding of the rules, and it allows young professionals from the various competent authorities to get to know each other and create the foundations for a future common supervisory culture.

ERA will continue to organise events, such as the annual conference on financial supervision and the summer course on financial supervision and regulation in the EU, to both follow its own mission of creating awareness and improving knowledge of EU law among those who put it into practice on a daily basis and, as a positive side-effect, to foster supervisory convergence across the EU. 